\title{
Russian-Vietnamese Cooperation in Energy Sector
}

\author{
Nguyen Thi Ngoc Lan, E.F. Chernenko \\ Peoples’ Friendship University of Russia (RUDN University), \\ Moscow, Russian Federation
}

\begin{abstract}
The abundance of energy resources including renewables and non-renewables is central to the development of energy sector. However, other decicive factors like technology and human resources turn naturally-bestowed gifts into economic gains for properity. In the circumstance of being an invaded country in the 1950s, the young Democratic Republic of Vietnam prioritized formation of energy sector in the economic development plan to be more self-reliant in energy security for a harsh war against much more powerful enermies. A single international source of supports for the very young country at that time was communist allies. The Soviet Union assumed a major responsibility as the largest benefactor for the Democratic Republic of Vietnam in the war-time. In addition to millitary and logistic aids for the Democratic Republic of Vietnam in North Vietnam to struggle with the US-backed Government of the Republic of Vietnam in South Vietnam for unification, the Soviet Union also actively supported it to implement the 5 -year economic plans for socialism development including formation and development of the energy sector. In the post-war time, they continued to support the newly-unified country, the Socialist Republic of Vietnam, to develop the energy sector as its spreadhead economic sector. The Russian Federation and Vietnam continue to deepen the bilateral cooperation in energy sector with the successful management of multibillion dollar joint-ventures in the oil and gas industry and implement many projects in the energy sector as a whole after the collapse of the Soviet Union. In assessment of the achivements of RussiaVietnam cooperation, the bilateral parternship in energy sector emerges as the most prominent area of cooperation over the 68-year old history of cooperation. This article is aimed to provide a brief history of bilateral cooperation in the energy sector with an emphasis on the central role of the Soviet Union and later Russian Federation in forming and developing the energy sector of Vietnam. Prospects of cooperation are also a matter of analysis in this article.
\end{abstract}

Key words: energy sector, oil and gas industry, bilateral cooperation, North Vietnam, South Vietnam, Soviet Union, Russia

\section{INTRODUCTION}

In the Southeast Asia, Vietnam has appeared as one of the most dynamic economies with the annual average growth rate of more than $6 \%$ over many decades since a comprehensive economic reform launched by the Government in 1986 for transition from centrally-planned to market economy. Vietnam reached to a lower middle-income country status in 2010. Remarkable economic growth is partly attributed to the energy sector, whose crucial role is to provide momentum for rapid industrialization. Population growth and governmental orientations for industrialization and modernization in almost socio-economic development plans since the economic reform, as known as "Doi moi" translate into a strong demand for maintaining energy security.

Actually, a special attention had been paid by the Government of Democratic Republic of Vietnam (DRV) for developing the energy sector since independence 
in 1945. The first president of the Democratic Republic of Vietnam, Ho Chi Minh, put development of energy sector high in the economic development agenda. On the occasion of his visit to Azerbaijan's Neftianye Kamni oil field in 1959, he nurtured a strong ambition of developing the oil and gas industry like this country in his mind with a saying that "after Vietnam wins in the war, the Soviet Union in general and Azerbaijan in particular must support Vietnam in exploring and processing oil and natural gas and developing as strong petroleum industrial zones as Baku"1. After more than 70 years, the energy sector has been growing as one of the most important economic sectors in Vietnam. Extracting the first cubic meter of natural gas in June 1981 and pumping the first tons of crude oil in June 1986 as two crucial milestones mark the progress of the Vietnam's energy sector. From a net energy importer, Vietnam has become an energy exporter in 1990s. When it come to the formation and development of Vietnam's energy sector, Russia's technical and financial assistance are of very substantial significance ${ }^{2}$.

A wide range of literatures on Russo-Vietnam cooperation is available. Most studies focus on analyzing stages of cooperation in chronological order, including general description on various areas of cooperation [Istomin 2018]. Unlike military cooperation, there are few studies on bilateral cooperation in energy sector [Mazyrin 2012; Mazyrin 2016; Kobelev 2015; Narkhova 2017]. Articles devoted to Russo-Vietnam relations appear in such journal as "South-East Asia: relevant problems of development" written by G.M. Kostunina [Kostunina 2018], A.Y. Skopin [Skopin 2018], M.S. Zelenkova [Zelenkova 2018], N.N. Tsvetkova [Tsvetkova 2015]. The latter has a lot of publications on common problems of Vietnam and is very famous as a scientific researcher both in Russia and abroad.

The most famous Russian scientific centers, which research different aspects of Vietnamese problems, are in Moscow (Institute of the Oriental Study and Institute of the Far East of the Russian Academy of Sciences), Petersburg and Vladivostok. The name of Vietnamese scientist Nguen Minh Ngoc is known as the author of two monographs [Nguen Minh Ngoc 2013a, 2013b] and the article [Nguen Minh Ngoc 2015], in which interests and policy of Japan, Russia, India and Australia in the South China Sea are under consideration. The content of the article is closely connected with our topic. Russian-Vietnamese relations are being researched not only in Russia and Vietnam. Japanese scientist Mikhoko Kato has published an article devoted to analysis of special features and tasks of development of the Russian-Vietnamese strategic partnership [Mikhoko Kato 2015: 54 -74]. Periodic publication "Vietnamese studies" of Institute of the Far East of the Russian Academy of Sciences regularly presents new collections of articles, where among different aspects of Vietnamese problems Russian-Vietnamese relations are touched upon. In the focus of the article by N. Filimonova are possibilities of cooperation in the Arctic of the two countries [Filimonova 2015].

Despite availability of relatively numerous bulletins about this partnership on both digital and non-digital newspapers in various languages, major Russo-Vietnam coopera-

${ }^{1}$ PetroVietnam. History of oil and natural gas industry in Vietnam until 2010. 2011. Vol. 1. National Publishing House of Politics and Truth. Hanoi, Vietnam. P. 23.

2 Asian Development Bank. Vietnam energy sector assessment, strategy and roadmap. December 2015. URL: https://www.adb.org/sites/default/files/institutional-document/178616/vie-energy-roadmap.pdf (accessed: 06.06.2018). 
tion achievements in energy sector are only referred with very few analyses about the role of the USSR and Russia in formulation and development of Vietnam's energy sector ${ }^{3}$. It is understandable that there are many stakeholders in this process but the USSR and later Russian Federation occupy a critical position. The purpose of this article is to explore the following main questions: How does history of Russo-Vietnam relations in energy sector help their modern cooperation? What role does the USSR and later Russian Federation play in the formation and development of Vietnam's energy sector? What are prospects for bilateral cooperation in energy sector? By answering these questions, it is argued that the Soviet Union was a pioneer supporter in the development process of Vietnam's energy sector and the Russian Federation presents itself as an excellent successor. The influential role of the Soviet Union in the past and the Russian Federation at present is singled out by arguing that the growth of Vietnam's energy sector is attributed to the financial, technical and personnel contribution since the war-time to now. Not only Vietnam but also Russia is very interested in nurturing cooperation in energy sector because of mutual economic and political gains. Within the scope of this article, it only emphasizes on economic benefits enjoyed by Vietnam from this permanent partnership. Political perspectives of this bilateral cooperation from both sides are not covered in this article ${ }^{4}$.

\section{ENERGY SECTOR IN RUSSIAN-VIETNAMESE RELATIONS: SHORT HISTORY}

For the development of energy sector in any country, availability of energy sources is very important factor. Vietnam has benefited from a large range of domestic primary energy sources such as crude oil, coal, natural gas and hydropower; however, the quantity of these sources is moderate to be capable of partially satisfying the current internal demand. In 1990s, Vietnam emerged in the world market as an exporter of crude oil and coal. However, the development of industrial and transportation sectors at the turn of the 20th century plus population growth rebalance the demand and supply of primary energy sources, deepening the country's dependence on external resources of oil products and some kinds of coal ${ }^{5}$.

\footnotetext{
${ }^{3}$ Russia strengthens ties with Vietnam // Forbes. December 12, 2013. URL: https://www.forbes.com/ sites/stratfor/2013/12/12/russia-strengthens-ties-with-vietnam/\#25989b487811 (accessed: 30.06.2018).

${ }^{4}$ Beginning of the meeting with the Secretary General of of the Communist Party of SRV Nguyen Phu Trong. URL: http://www.kremlin.ru/events/president/transcripts/by-date/06.09.2018. (in Russian).

5 Vietnam: oil consumption // Global Economy. 2014. URL: https://www.theglobaleconomy.com/ Vietnam/oil_consumption/ (accessed: 04.06.2018); Vietnam crude oil production // Tradingeconomics. 2018. URL: https://tradingeconomics.com/vietnam/crude-oil-production (accessed: 14.06.2018); Thuy Linh. Crude oil export and import increase strongly. December 24, 2017. URL: http://cafef.vn/xuatkhau-dau-tho-tang-nhap-khau-xang-dau-cung-tang-manh-20171224093000069.chn (accessed: 04.06.2018) (in Vietnamese); Vietnam: coal export // Global Economy. 2014. URL: https://www.theglobaleconomy.com/Vietnam/coal_exports/ (accessed: 14.06.2018); Vietnam imports 3 million tons of coal to operate 3 PVN's thermal power plants each year. November 2, 2016. URL: http://dantri.com.vn/kinh-doanh/moi-nam-nhap-15-trieu-tan-than-cho-3-nha-may-nhiet-dien-cua-pvn20161102202328594.htm (accessed: 26.06.2018) (in Vietnamese); DTPS. Report on prospects of coal industry in Vietnam. June 27, 2017. URL: https://dautuphaisinh.com/bao-cao-trien-vong-nganhviet-nam/ (accessed: 14.06.2018) (in Vietnamese); ATIC. Oil and gas to Vietnam — Trends and
} 
Traditional partners of Vietnam come from the Russian Federation such as Zarubezhneft and Gazprom, which continue to play an important role in the oil and gas industry of Vietnam. Many jointly-implemented projects in the oil and gas industry have been implemented for many decades, bringing millions of US dollars to two governments. It is a true fact that cooperation in the oil and gas industry has been always played a crucial role in the bilateral economic cooperation. Two countries also have cooperated very strongly not only in gas and oil industry but in the power sector as a whole since 1960s [Cherry 2018; Baev, Tonnesson 2015]. Looking back the development history of Vietnam's energy sector, it is undeniable that the Soviet Union supported Vietnam to lay out a foundation for its energy sector, particularly gas and oil industry. After the collapse of the Soviet Union, the Russian Federation inherits this traditional and strategic bilateral cooperation, particularly in the energy sector. Until now, this relationship has a life of more than 65 years.

After the collapse of the USSR, the Russian Federation experienced profound structural changes in the economic, political and social system. The 40 -year bilateral cooperation also faced massive interruptions caused by the dissolution of the world's largest communist country. It seemed that this bilateral cooperation nearly came to the status of stagnation in some first years. As an important international benefactor of Vietnam during the war-time, the USSR provided a very huge ideological, material and spiritual supports to Vietnam, evidently forming a very special position in the hearts and minds of the public and the leadership in Vietnam. During this period, an influential generation of policy makers such as General Secretary of Vietnam Communist Party, Nong Duc Manh; Defense Minister, Phung Quang Thanh; National Assembly Chairman, Nguyen Phu Trong, and others who studied and lived in the USSR for many years, continued to maintain their warm feelings to the Russia and desired to improve cooperation with the Russian Federation as Vietnam used to enjoy with the USSR. A series of official visits by the political leaders from two sides since 1994 gradually helped both countries to move beyond the sense of uncertainty, stagnation, and aloofness within their relationship.

The first event earmarking the progress to improve the Russo-Vietnam relationship is an official visit by the Vietnamese Prime Minister Vo Van Kiet to the Russian Federation in June, 1994. In this trip, the Treaty on principles of friendly relations between the Socialist Republic of Vietnam and Russian Federation defining main principles of bilateral cooperation in the post-Soviet Union was signed by two countries as substitute of an obsolete Treaty of Friendship and Cooperation signed by the Soviet Union and the Socialist Republic of Vietnam in November 4, 1978, in Moscow. Bilateral cooperation in energy sector in general and oil and gas industry in particular is among key aspects in the newly-concluded treaty. Three years later, the Russian Prime Minister,

opportunities. 2017. URL: https://www.austrade.gov.au/australian/export/export-markets/countries/ vietnam/industries/oil-and-gas (accessed: 10.06.2018); OGAV. Vietnam's oil and gas industry on a continuing growth path. 2018. URL: http://oilgasvietnam.com/post/97/Industry-Facts.html (accessed: 12.06.2018); Vietnam swifts from top coal exporter to a coal importer// Baomoi. October 24, 2017. URL: https://baomoi.com/tu-mot-quoc-gia-xuat-khau-than-hang-dau-viet-nam-ngay-cang-phu-thuocthan-nhap-khau/c/23681155.epi (accessed: 14.06. 2018). 
V.S. Chernomyrdin, paid a visit to Vietnam. However, these high-ranking visits were not sufficient to revitalize the bilateral cooperation. Generally, the focus of discussions mainly involves write-off of debts owned by Vietnam to the Russian Federation and expansion of the payment of the balance. The level of cooperation in investment and trade, education and others was limited in size during this period.

A new stage of Russo-Vietnam relations was ushered with the Joint Statement for a Strategic Partnership signed by two parties in the first official visit of the Russian President, V.V. Putin, to Vietnam in March 2001. The crucial inter-governmental agreement has underpinned the steady, but gradual, evolution of the bilateral relationship in the first decade of the new century [Kozyrev 2014: 8-11]. Among eight major areas set out by the intergovernmental agreement is energy cooperation. It is a matter of fact that at the turn of the century, bilateral trade between Moscow and Hanoi reached the lowest level in officially recorded history (200 million USD), accounting for less than one percent of Russia's foreign trade volume [Kozyrev 2014: 8-11]. However, cooperation in energy sector, particularly gas and oil industry was effective. In 2002, 13.52 million tons out of 17 million tons as the Vietnam's crude oil output was pumped by Vietsovpetro and constitutes the bulk of Vietnam's oil exports ${ }^{6}$. The jointventure enables Vietnam to confirm it as the third largest oil exporter in the Southeast Asia. Meanwhile, Russia earned 321 million USD of the profit from Vietsopetro in the first nine months of $2002^{7}$.

Following the formation of strategic partnership in 2001, five high-profile visits by key political leader of Government of Vietnam to Russia with an aim of reinforcing the mutual cooperation and promoting trade and investment have been paid, including (i) the General Secretary of Vietnam Communist Party, Nong Duc Manh, in October, 2002; (ii) the Chairman of National Assembly, Nguyen Van An, in January, 2003; (iii) the President, Tran Duc Luong in May, 2004, (iv) Prime Minister, Nguyen Tan Dung in September, 2007 and (v) the standing secretary of Vietnam Communist Party, Truong Tan Sang in June, 2008. Many return visits from the Government of Russia were undertaken by key leaders such as (i) Prime Minister of the Russian Federation M.M. Kasyanov in March, 2002, (ii) Chairman of the Federation Council S.M. Mironov in January, 2005, (iii) Prime Minister of the Russian Federation M.E. Fradkov in February, 2006, etc. Oil and gas exploration and exploitation had been always a priority issue in discussion in all high-ranking visits of key leaders. Two out of five important documents of bilateral cooperation signed by the Russian President V.V. Putin, on his second visit to Vietnam and the Vietnamese President, Nguyen Minh Triet in 2006 relate to the energy sector, in which the first is about a joint discussion on cooperation on oil exploration gas in the southern continental shelf of Vietnam and the second about cooperation between Russian's joint-stock company, Gazprom and Vietnam National Oil and Gas Company (PetroVietnam).

${ }^{6}$ GIC. Oil and gas exploration laws and regulation handbook. 2008. Vol. 1: Strategic and legal information. International Bussiness Publications, USA. P. 179.

${ }^{7}$ Ibid. 
The second decade of the twenty first century actually records an impressive improvement in the bilateral relationship when the strategic partnership was officially upgraded into the status of a comprehensive strategic partnership in a state visit by Vietnamese President Truong Tan Sang to the Russian Federation in July, 2012. The Russian President V.V. Putin and the Prime Minister D.A. Medvedev made return visits to Vietnam in November, 2013 and April, 2015 respectively. In this period, there were also other official visits from Vietnam's key leaders. The most recent state visit (June, 2017) by Vietnam President Tran Dai Quang to the Russian Federation proposed measures for strengthening bilateral cooperation, particularly in energy sector. Establishment of the Nuclear Science and Technology Center in Vietnam was among topics of discussion in this trip.

One of joint-cooperation components contributing to the building-up of a strong sense of political confidence and trust on the both sides is joint-oil and gas exploration in offshore Vietnam. The 1.5 billion-Vietsovpetro with $51 \%$ of shares held by PetroVietnam presenting the Vietnamese side and $49 \%$ by Zarubezhneft presenting the Russian side continues stand out as a bright example of successful operation in the energy sector. At the end of 2013 production of the whole industry has exceeded 268.31 million tons of crude oil, including 189.9 million tons from Vietsovpetro and 78.3 million tons from PVEP (PetroVietnam Exploration Production Corporation) [Le Viet Trung et al. 2016: 64-71]. Over 37 years of operation, this joint venture has been awarded 18 honorable orders of the Socialist Republics of Vietnam in total including Gold Star Order, Ho Chi Minh Order, Hero of Labor Titles (different levels), Independence Order, Military Exploit Order (different levels), Labor Order (different levels), Feat Order (different levels) and National Security Medal. It is among few joint-ventures in Vietnam having been honored with the "Gold Star Order", the most notable award in the country's order and medal system on the 30th anniversary of establishment in 2010, acknowledging its great contributions to the oil and gas industry in particular and national economic development in general. Another symbol of the strategic traditional relationship is Rusvietpetro, a jointventure between Zarubezhneft and PetroVietnam at the stake of 51/49. This company came into operation in December, 2009. Currently, it is prospecting, exploring and exploiting 13 fields of 4 blocks in the Nenetsky autonomous region, Russian Federation. At the end of 2015, the accumulative production output reached more than 19 million tons, bringing the total revenue of more than 5.5 billion USD. This enterprise was also granted with a Friendship Order by the GoV.

In the oil and gas joint-cooperation field, Vietnam has come into agreements with numerous international groups from United States, Japan, Russia, UK, Malaysia, Canada, and Australia. However, the Russian Federation remains the largest partner since the first days of the gas and oil industry. In addition to Zarubezhneft holding 49\% in the first joint-venture of this type in Vietnam, Vietsovpetro, 50\% in the Vietnam - Japan - Russia Petroleum Company (VRJ) and 51\% in Rusvietpetro, two other Russian giant groups are keeping influential positions in the Vietnam's oil and gas industry when being granted with licenses to operate in oil and gas fields or structures of high commercial values. Gazprom, Russia's largest producer and exporter of liquefied natural gas, set up business relationship with PetroVietnam in the form of Protocol on cooperation signed in 1997 and officially operated in Vietnam's off-shore waters in 2002. A first product of joint coope- 
ration is Vietgazprom, which is currently conducting exploration activities at eight oil and gas licensed blocks on the continental shelf of Vietnam. It is important to note that Gazpromviet joint-venture, a second product of joint cooperation, registered in 2010 enables PetroVietnam to operate abroad, particularly in the Nagumanovskoye (Orenburg Region) and Severo-Purovskoye (Yamal-Nenets Autonomous Area) fields, both in Russia. This group also inked a contract with Petrovietnam Gas Joint Stock Corporation for forming the PVGAZPROM Natural Gas for Vehicles Joint Venture (PVGAZPROM NGV) in October, 2015 with the target of producing and marketing natural gas as a vehicle fuel in Vietnam. The latest investor from the Russian Federation to Vietnam's oil and gas industry is Rosneft, the Russia's largest oil producer. With the establishment of Rosneft Vietnam B.V. in 2013 to operate the block 0.61 and block 05-3/11 and Rosneft Pipelines Vietnam B.V. to manage a pipeline that carries gas and condenses from four offshore blocks to an onshore power generation plant, the group affirms its important role in Vietnam's energy security by producing $10 \%$ of Vietnam's electricity needs and 65,000 tons of gas condensate in 2017. This group owns around $33 \%$ of the stake in the block 0.61 and the pipeline. In addition to profitability, experiences gained though operation offshore Vietnam are believed to be useful for planning and implementation of exploration and production projects in the other remote regions of the world.

In this period, two countries continue to expand the history of cooperation in the hydropower sector. Construction of $720 \mathrm{MW}$ Yaly hydropower plant on the Sesan River, a main tributary of Mekong River in Central Vietnam in 1993 is an example. This plant is different from other large constructed hydropower plants because it was the first time that Vietnam is responsible for managing and organizing the entire construction process under the technical supervision of Russian and Ukrainian specialists. The plant consists of four generators, the first of which came into operation in 2000 and the last of which in 2001. At the time of construction, this plant is the second largest one in the country, after Hoa Binh Hydropower Plant. This plant plays a crucial role in the country's electricity system because it supplies more 3.68 billion kWh per year, addressing serious shortage of electricity in dry season and helps to adjust frequency and voltage of the country's grid system. A recently-completed 2,400 MW Son La Hydropower Plant on Black River in the north of Vietnam makes a considerable contribution to fulfilling the target of increasing the country's hydropower capacity to $75,000 \mathrm{MW}$ by $2020^{8}$. After 7 years of construction (2005-2012), this 6-generatorplant came into operation to supply over 10,000 billion $\mathrm{kWh}$ per year, inscribing it as the largest hydropower plant in Vietnam and Southeast Asia. Its concrete gravity 961.6 meter-long and 228.1 meter-high dam coupled with the 9.26 billion-cubic-meter reservoir is very useful to regulate and supply water to the Red River Delta, the second most important rice-cultivating delta in Vietnam. It is a great pride that the plant was completely built by Vietnamese contractors based on the technical design by the institute

${ }^{8}$ GoV. Decision on approving the national power development plan until 2020. 2011 // Government in Vietnam. URL: https:/thuvienphapluat.vn/van-ban/Linh-vuc-khac/Quyet-dinh-1208-QD-TTgphe-duyet-Quy-hoach-phat-trien-dien-luc-quoc-gia-126942.aspx (accessed: 14.06.2018) (in Vietnamese). 
"Hydroproject", Russian hydro-technical design firm, showing Vietnam's mastery of hydropower technologies. This institute is also responsible for technical-designing for many important hydropower projects in a wide range of scales such as Yaly, Tri An, Ham Thuan and others.

\section{ROLE OF RUSSIA IN FORMATION AND DEVELOPMENT OF ENERGY SECTOR IN VIETNAM}

The role of the USSR and Russian Federation in energy security in Vietnam is very huge. First of all, Vietnam was nearly completely reliant on the supply of petroleum from Russia to support industrialization in North Vietnam and fight the "War of Liberation" in South Vietnam. Millions of tons of petroleum were transported to Vietnam during the war. In 1980s, the newly-reunified country faced an economic recession and population boom. A serious shortage of basic commodities was commonplace across the country. In 1983, 90\% of petroleum, iron, steel, fertilizers, cotton and $70 \%$ of grains demanded by the country were provided by the Soviet Union. The situation only started to change after the first oil field of Vietnam, Bach Ho, came online in 1986. In early 2000s, Vietnam was in the top-three crude oil exporter in the Southeast Asia. The constantly-increasing demand of energy brings Vietnam from a net energy exporter to net energy importer in 2015. As expected, the domestic demand of coal reaches 86.5 million tons by 2020, 121.5 million tons by 2025 and 156.6 million tons by 2030 . Due to supply-demand imbalance, 36.4 million tons, 67 million tons and nearly 100 tons need to be imported in 2020, 2025 and 2030 respectively. In recent years, coal has become a key export commodity to Vietnam from the Russian Federation. For example, Russia exports more than 1 million tons of anthracite coal to support the operation of thermal power plants to Vietnam each year.

Secondly, the USSR helped Vietnam to lay out a foundation for the oil and gas industry. Since the early days, Vietnam has received generous support from the Soviet Union to carry out geological surveys to prospect oil and gas potentials in term of financial, technical and human resources. The first generation of Vietnam's oil and gas specialists and engineers came from practical trainings by Soviet specialist in field trips. Through development and production activities, PetroVietnam's technical capability has been developed and PetroVietnam is nowadays capable of operating development and production activities in the deep water and off-shore areas [Le Viet Trung et al. 2016: 64-71]. Since 1990s, the Russian Federation maintains profitable cooperation in this industry. Three major oil and gas groups, Zarubezhneft, Gazprom and Rosneft have worked with Vietnamese partners in many effectively-operating joint-ventures. A half of the total output of crude oil in Vietnam has been produced by VietsoPetro, ranking it as the highest revenue-making company with foreign capitals which are operational in the Vietnam's oil and gas industry. It is wonderful that this state-owned oil and gas group of Vietnam expands its operational scope beyond Vietnam's offshore waters in partnership with Russian partners. In the face of diminishing output from the mature oil fields, PetroVietnam is cooperating with Russian partner in prospecting and exploring other oil and gas structures to compensate a drop from the major mature oil field like Bach Ho. In term of income-generating, the formation and growth of Vietnam's oil and gas industry empowers its national economy to escape from a group of the world's 
poorest countries after liberation in 1975 to reach the status of lower-middle income countries. That being said, PetroVietnam, a state-own oil and gas group responsible for oil and natural gas resources in Vietnam, has an average growth rate of nearly $20 \%$ per year and makes a contribution of $20-25 \%$ of the entire state budget over three decades since commercial exploration of crude oil in Vietnam ${ }^{9}$.

Thirdly, influence of Russia in the power sector is something undeniable. Key hydropower and thermal power plants like Yaly, Son La, Hoa Binh, Pha Lai and Uong Bi etc. were designed by Russia and constructed with their technical and financial support. A physical challenge faced by Vietnam is constantly-serious shortage of electricity despite a fact that hundreds of hydropower plants and dozens of thermal power have been operated so arr $^{10}$. In the period $2011-2015$, the national electricity consumption grew at the average rate of $10.6 \%$ per year, which was lower than the average growth of the period 2006-2010 at $13.4 \%$ per year ${ }^{11}$. The demand of energy is expected to remain above $10 \%$ until $2030^{12}$. Each power plant constructed in each region helps to reduce pressures of distribution over the national grid, particularly in dry months. Financially, many hydropower and thermal plants constructed during the war-time and post-war period are completely funded by the Soviet Union in form of grants. Nowadays, the Russian Federation continued to provide million-USD loans to the GoV to make investments into new hydropower projects. For example, 100 billion USD loan was offered by the Russian Federation at the preferential interest of $4.25 \%$ to purchase equipment for two hydropower plants, namely SeSan 3 and Pleikrong. With the installed capacity of $130 \mathrm{MW}$, the electricity output of the first, which was completed after 5 years of construction from 2002 to 2006, reaches 611 million Kwh per year. The latter constructed from 2003 to 2009 is smaller at $100 \mathrm{MW}$ and 417 million $\mathrm{kWh}$ per year.

Fourthly, it is important to note dominance of the Russian technology in coal industry power sector. In the coal industry, the USSR-manufactured drilling machines, loaders, haulers and supporting equipment have been commonly seen in many surface

${ }^{9}$ Cooperation projects with Russia expands in both areas of cooperation and scope of operations // PetroVietnam. September 29, 2017. URL: http://www.pvn.vn/Pages/detail.aspx?NewsID= 7bfed109-1bf5-4362-9ebb-07d98338ab2c (accessed: 26.06.2018).

10 See: Confessions of a hydropower calamity in Vietnam // Vnexpress. 2017. URL: https:/e.vnexpress.net/ projects/confessions-of-a-hydropower-calamity-in-vietnam-3655314/index.html (accessed: 14.06.2018); IHA. Vietnam Energy Online (2015). Vietnam Renewable Energy Development Strategy. November 29, 2015. URL: http://nangluongvietnam.vn/news/en/nuclear-renewable/vietnam-renewableenergy-development-strategy.html (accessed: 14.06.2018); MoF. Factsheet on renewable energy in Vietnam. 2017. URL: https://www.rvo.nl/sites/default/files/2017/11/factsheet-renewableenergy-vietnam.pdf (accessed: 14.06.2018); Hydropower Status Report 2017. URL: https://www.hydropower.org/sites/default/files/publications-docs/2017\%20Hydropower $\% 20$ Status $\% 20$ Report.pdf (accessed: 04.06.2018).

11 DEA. Vietnam energy outlook 2017. URL: https://ens.dk/sites/ens.dk/files/Globalcooperation/ Official_docs/Vietnam/vietnam-energy-outlook-report-2017-eng.pdf (accessed: 30.06.2018).

12 See: Khac Kien. Electricity demand in Vietnam increases by $10 \%$ each year. July 31, 2017. URL: http://kinhtedothi.vn/nhu-cau-dien-o-viet-nam-tang-them-10-moi-nam-294327.html (accessed: 20.06.2018) (in Vietnamese). 
coal mines in Vietnam. It is even more prominent in the power sector. Key hydropower and thermal power plants from Thac Ba to Son La were constructed in use of Russian technology and equipment. Power Machines, a Russia's world-leading power engineering company, has a very long-standing cooperation history with Vietnam which dates back to 1960s when this group provided generators to Thac Ba Hydropower Plant, the largest hydropower plant in North Vietnam at that time. Later, the group was contracted to supply cutting-edge and highly-efficient sets of power equipment for other hydropower plants such as Tri An and Hoa Binh and thermal power plants like Uong Bi and Pha Lai until 1990s. In the new century, the list of Vietnam's clients also embraces $132 \mathrm{MW}$ SeSan 3 Hydropower Plant, 153 MW Pleikrong Hydropower Plant, 210 MW-A Vuong Hydropower Plant, 280 MW Buon Kuop Hydropower Plant and 1,200 MW Long Phu 1 Thermal Power Plant. Additionally, this company was selected to supply equipment and repairing services for many long-serving plants such as upgrading Uong Bi Thermal Power Plant from $153 \mathrm{MW}$ to $300 \mathrm{MW}$ in 2002 and equipping Pha Lai 2 Thermal Power Plant in 1998 next to Pha Lai 1 Thermal Power Plant constructed in 1986. The capacity of generator systems installed and manufactured by Power Machines is expected to reach 4,500 MW, accounting for nearly $15 \%$ of total capacity in Vietnam ${ }^{13}$.

Last but not less, Russia plays an important role in training human resources working in the energy sector of Vietnam. Looking back the history of the energy sector, the Soviet specialists and engineers dedicatedly coached Vietnamese technicians and engineers how to apply advanced technologies in geological surveys in 1950s. At this time, not many Vietnamese were sent abroad to receive adcademic training related to energy-specific disciplines. In Vietnam, almost the Vietnam's universities having been established after independence remained inexperienced in instructing these disciplines because they themselves did not have sufficient high-qualified lecturers. Having implementing a personel-training policy set by the Government of the Democratic Republic of Vietnam, well-performed students from high schools in North Vietnam were selected to pursue the tertiary education program on energy-related disciplines at reknown universities in the Soviet Union and its sattelite communist countries such as Russian State Geological Prospecting University, Gubkin Russian State University of Oil and Gas, National Research University, Petroleum-Gas University of Ploiesti, Azerbaijan State Oil and Industry University and others. Graduates worked in the oil and gas industry after graduation. Many of them held key positions in this industry. Nowdays, hundreds of Vietnamese students are following graduate and post-graduate programs at the above universities under the Russian-offered scholarship and fellowship. Acknowledging the contribution of univerisites in training human resources for Vietnam and maintaining the bilateral relationship, the GoV awarded honorable orders to these universities. For example, Gubkin Russian State University of Oil and Gas was granted with the Labor Order (Level III) and Friendship Order and the Moscow Power Engineering Institute with Labour Order (Level I) and Friendship Order.

13 See: Power Machines organizes client conference // PetroTimes. August 16, 2017. URL: http://petrotimes.vn/power-machines-to-chuc-hoi-nghi-khach-hang-497918.html (accessed: 21 June 2018). (in Vietnamese). 


\section{PROSPECTS OF RUSSO-VIETNAM COOPERATION IN ENERGY SECTOR}

Energy system in Vietnam consists of four sectors including oil and gas industry, power sector, coal industry and a newly-formulated renewable sector. When it comes to Russo-Vietnam cooperation in energy sector, both countries have so far concentrated in oil and gas industry and power sector. There are some good prospects of cooperation in coal industry and peaceful nuclear energy. As for renewable sector, Russo-Vietnam cooperation remains nothing.

Cooperation in oil and gas industry: Both states concentrate as many as resources on deepening cooperation in petroleum industry through successful management of energy projects. In recent years, the status of cooperation has been two-directional with the presence of PetroVietnam in oil and gas exploration and exportation in the Nenets Autonomous Region and in the Orenburg Region in form of joint-venture. However, the current projects are mainly in prospecting, exploring and exploiting hydrocarbon resources. It is of significance to diversify forms of cooperation rather than extraction as mentioned by the Russian Prime Minister D.A. Medvedev in an interview ahead an official visit to Vietnam in 2015. However, Russia's involvement in refining projects appears not easy at all. Gazgrom Neft used to be a key stakeholder of the Dung Quat oil refinery upgrade and expansion project. Dung Quat refiner is the first of four operational refinery facilities across Vietnam. It was planned that Gazgrom Neft would acquire $49 \%$ share, equivalent to its investment, in the upgraded refinery upon completion. Gazgrom Neft together with two other investors from Japan (JX Nippon) and Venezuela (PDVSA) withdrew from the project as consequence of failure in applying for an extension of tax incentives for this project. Another Russian energy company, Rosneft, a strategic partner in Nhon Hoi mega-refinery project which is expected to produce 400,000 barrels per day, had not been able to realize had not been able to realize this project as it was officially cancelled after many delays caused by reduction in investment capitals and failure in obtaining the licensing documents. When it comes to territorial disputes over marine's features the South China Sea, oil and gas exploration and exploitation on the continental shelf of Vietnam are subject to some certain pressures from China, a powerful claimant. For example, China National Petroleum Corporation attempted to auction disputed hydrocarbon blocks in 2012 in the Nam Con Son basin housing important gas and oil structures of Vietnam. Gazprom and Rosneft have exploration and drilling activities at these disputes blocks. Energy projects in cooperation with Russia are important to the state finance on the side of Vietnam.

Cooperation in power sector: This aspect is as traditional as cooperation in petroleum sector. The Russian Federation occupies a very key position in the development of hydropower and thermal power plants since the war-time. At present, Vietnam is completely dependent on hydropower and thermal power supplies. It was unfortunate the large hydropower potentials on the major river system of Vietnam have been almost exploited and under great impacts by climate change. Thermal power plants have been criticized for environmental problems. A heavy pressure imposed by the very quickly- 
increasing demand for electricity motivates the Government of Vietnam to diversify the sources of supply. Both countries have a very high expectation to cooperation with each other in nuclear power. After many years of discussion, a plan was adopted by the Government of Vietnam to construct two nuclear power plants in use of Russian technology and Japanese technology respectively in 2009. The first plant that was planned to be built by the State Atomic Energy Corporation of Russia (ROSATOM) would consist of four Russian-designed reactors (VVER-1000) to reach a capacity of 4,000 MW. The construction of this plant was also financed from the Russia-offered 8 billion USD preferential loan. Despite completion of a feasibility study, construction was postponed in several times and officially abandoned in 2017 on the side of Vietnam in consideration of cost-effectiveness, safety issues and financial viability. Cancellation appears an economically-sound decision in a context that the investment costs doubling to 18 billion USD as compared with the 2009 estimate definitely worsen Vietnam's public debt, which is nearing the government's ceiling of $65 \%$ of GDP and some other cheaper alternatives (electricity supply from solar and wind energy or purchase of electricity from neighboring countries) are available. However, this unexpected decision is regretful case as an immense amount of resources have been spent by both sides for a series of surveys and negotiations over several decades. There are no concrete figures of economic wastes released by both sides but several years of work were believed to cost both economies in a considerable amount of US dollars. This cancelation strengthens Vietnam's determination to accelerate construction of coal-fired and gas-fired thermal power plants to compensate a shortage of electricity, particularly in the southern region of Vietnam. Russian energy and machine companies get some involvements in these projects. For example, the Russia's Power Machines, one of three consortium members of the project on constructing the first of three coal-fired thermal plants in Long Phu District, Soc Trang Province. This group having been accumulated abundant experiences in supplying power equipment for a wide range of thermal plants over many decades in Vietnam won a contract for equipping the 1,200 MW plant which is designed to supply approximately 7.8 billion $\mathrm{kWh}$ annually to the national grid. Russia-based Bank for Development and Foreign Economic Affairs, Vnesheconombank (VEB), one of Russia's largest financial institutions, is among financiers for the project. Credits supplied by the bank are used to pay for high-tech power equipment including associated services from the Russian Federation.

Cooperation in coal industry: The decision to cancel the nuclear power plant projects means that the Government of Vietnam has to more rely on thermal power and purchase of electricity from neighboring countries. More dependence on fossil fuels for electricity supply brings about more environmental problems and demands more hydrocarbon resources and coal. Russia is now the Vietnam's third largest coal supplier, after Indonesia and Australia. Annually, 2 or 3 million tons of coal are purchased by Vietnam to meet the domestic demand and big share of imported coal is channeled to the coal-fired thermal power plants. It is anticipated that Vietnam still remains a client of Russian's coal companies in future. Additionally, Russian mining-technology companies find opportunities of cooperation with Vietnam's National Coal and Mineral 
Industries Group (Vinacomin) in provision of technology packages for improving efficiency and effectiveness of the Vietnam's coal industry which is now under tense competitive pressures. Rising production costs, outdated technology, low effectiveness and efficiency, among others, rise up the price of domestically-produced coal, around 10-15 USD higher per ton than imported coal. At the end of 2017, around 10 million tons were in stock but thermal power plants spent millions of US dollars on imported coal. Vietnam's coal mining industry has no way to modernize their technology and improve efficiency and effectiveness, thus reducing their production costs. Hence, efficiency-driven technological modernization in prospecting, extraction, processing and usage of coal is of an utmost important requirement in the coal industry development strategy until 2020, visioning to 2030, which encourages expansion of international cooperation in search of suppliers of advanced technologies. This opens an opportunity of cooperation for international companies to export their technologies to Vietnam. Dominance of the USSR-manufactured equipment in coal mining was obvious. However, most of equipment, mainly manufactured in the former USSR from 1960s onwards is of now of either obsoleteness or low-efficiency. Russian companies have chances to replace them with improved technologies. It is certain that Russian companies will face a strong competition from other international companies, which desire to deepen their involvement in modernization and automation of coal mining industry in Vietnam. Vist Group, well-known for deployment of the Kraier mine fleet management systems across Russia and CIS countries, saw a prospect of cooperation with Vinacomin to export their technology to the currently-operational surface coal mines of Vietnam. This deployment of the system, if successfully, promises to increase around $15 \%$ of efficiency of coal production at the currently-operational surface coal mines of Vietnam.

Cooperation in nuclear energy: Abandonment of the nuclear power plant projects will not put a stop for bilateral cooperation in this aspect. As confirmed in the intergovernmental agreement of 2011 and a joint statement of 2017, the Russian Federation will assist Vietnam financially and technically to construct the Nuclear Science and Technology Center at the aim of boosting Vietnam's capability of using atomic energy for peaceful utilization such as in healthcare, industry and agriculture. A promise was made by the Government of Russian Federation to provide a preferential loan of 500 million USD to finance the construction of the center. If the project runs successfully, it marks the second time of assistance from Russia. The first time was in 1984 when the Soviet Union helped to upgrade Dalat Nuclear Reactor (TRIGA-MARK II) from $250 \mathrm{kWt}$ to $500 \mathrm{kWt}$ by refueling it with 140 packs of WWR-M2 High Enriched Uranium (HEU) fuel of $36 \%$ U-235. This single reactor was built under the Atoms for Peace Program by the United States and came operational in 1963. It shut down over a period 1968-1975 in face of the escalated American War in Vietnam. Before the fall of US-backed Government of the Republics of Vietnam in South Vietnam, the core and fuel of this reactor were removed and returned to the United States. At present, this reactor is merely capable of meeting $30 \%$ of the demand of radioisotopes. The second time of assistance enables Vietnam to produce sufficient radioisotopes upon completion expectedly in 2025 . 
In the course of the official visit of the Secretary General of the Communist party of Vietnam Nguyen Phu Trong to the Russian Federation in September 2018 and his meetings with the President of the Russian Federation V.V. Putin and the Chairman of the Government of the Russian Federation D.A. Medvedev a whole series of the most important documents, which concerned different spheres of Russian-Vietnamese collaboration were signed ${ }^{14}$. As an example, the Memorandum about the development of collaboration in the sphere of the deliveries of liquefied natural gas and development of gas electro-generation ${ }^{15}$. This document is directed toward the development of doublesided interaction along the scientific research works, the exchange of experience and by the practical models of work in the sphere of liquefied natural gas and gas power stations. In other words, the promising trends of Russian-Vietnamese collaboration are deliveries of Russian liquefied natural gas into Vietnam, and also production and realization of gas-engine fuel.

The discussion deals also with the Russian participation in the development of the corresponding infrastructure for the newly created yields for electric energy generation for the market of Vietnam. Russian Gazprom has plans on the building regasification terminals in Vietnam and the network of gas-distributing stations in the south of the country. Furthermore, interest in the Vietnamese market recently manifests new player in the person of Novatek. Russia and Vietnam agreed to enlarge interaction in the petroleum, gas and in other promising sectors ${ }^{16}$.

\section{CONCLUSION}

Since the first days after independence, a special attention has been paid by the young Democratic Republic of Vietnam to develop the energy sector. During the wartime, Vietnam was heavily dependent on logistical supply by international benefactors, in which the leading country is the Soviet Union. Millions of tons of logistics and weapons were shipped from the Soviet Union to Vietnam directly or in transit at the third country. After the war, the Soviet Union continued to supply Vietnam with many basic commodities including petroleum products. In addition with generous flows of aids, they also actively supported Vietnam to conduct geological surveys to prospect minerals and natural resources, particularly hydrocarbon resources. In 1990s, Vietnam started to export

\footnotetext{
14 Vladimir Putin received General Secretary of the Communist Party of the Socialist Republic of Vietnam Nguyen Phu Trong, who is in Russia on an official visit // Embassy of the Russian Federation in the Socialist Republic of Vietnam. URL: https://vietnam.mid.ru/web/vietnam-en/ main/-/asset_publisher/JR0sSxNIVFWP/content/vladimir-putin-received-general-secretary-of-thecommunist-party-of-the-socialist-republic-of-vietnam-nguyen-phu-trong-who-is-in-russia-on-anofficial?inheritRedirect=false (accessed: 23.09.2018).

${ }_{15}$ Memorandum about the mutual understanding between the ministry of power engineering of the Russian Federation and the ministry of industry and trade of the Socialist Republic of Vietnam about the development of collaboration in the sphere of the deliveries of liquefied natural gas and development of gas electro-generation. URL: http://www.kremlin.ru/supplement/5334 (accessed: 23.09.2018). (in Russian).

16 Press statements following Russian-Vietnamese Talks // President of Russia. September 6, 2018. URL: http://en.kremlin.ru/events/president/transcripts/58474 (accessed: 10.09.2018).
} 
first tons of coal and oil to world market. Oil and gas industry has become one of the key pillars of Vietnam's economy. Construction of numerous thermal and hydropower plants during and after the war with the financial and technical support of the Soviet Union has made substantial contributions to socio-economic development of Vietnam. Therefore, it is reasonable to argue that the growth of Vietnam's energy sectors was shaped with the financial, technical and personnel assistance of the Soviet Union. Despite some years of interruption, the Russian Federation continues the long-standing and firmly-built bilateral cooperation. Nowadays, Russian energy companies such as Rosneft, Gazprom and Zarubezhneft are holding very influential positions in the oil and gas industry by running billion-dollar joint-ventures together with Vietnam Oil and Gas Group (PetroVietnam), earning billion US dollars for both governments.

Both Vietnam and Russian Federation are very interested in maintaining the partnership in energy sector because of profitability. The current global political and economic situation constitutes as a main driver for the Russian Federation to strengthen ties with Vietnam in energy sector. Western sanctions, combined with European attempts to become less dependent on Russian gas, have made a turn to Asia more desirable for Moscow [Filimonova 2015]. For this reasons, possibilities for bilateral cooperation in energy sector are always available. To be specific, energy projects on prospecting, exploration and exploitation of hydrocarbon resources on the continental shelves of both countries always remain high on the agenda of bilateral cooperation. Strong political willing from both states for maintaining and expanding bilateral cooperation in the oil and gas industry beyond the traditional way of cooperation, e.g. extraction will pay a way for two states to diversify forms of cooperation. It was unfortunate that construction of the first nuclear power plant in Vietnam was canceled due to safety cautions and financial viability after many efforts of discussion. Nevertheless, the abandonment of billion-dollar nuclear power plant projects has not put a stop for bilateral cooperation in nuclear energy. The Nuclear Science and Technology Center to be set up in use of Russian technology and finance as confirmed in the Russo-Vietnam Joint Statement of July, 2017 will help Vietnam to produce radioisotopes in support of peaceful utilization in healthcare, agriculture and industry. Other opportunities of cooperation for providing Russian technologies to modernize the Vietnam's coal-mining industry and expand the Vietnam's electric generation have been exploited in maximum by Russian companies.

Russian Prime Minister's visit to Vietnam in November, 2018 confirmed friendly relations between the two countries and intention to continue cooperation in different directions including energy ${ }^{17}$.

Acknowledgments: The study was carried out within the framework of the research work of Russian Foundation for Basic Research N 18-514-92003/18.

17 News conference by Dmitry Medvedev on the outcome of the APEC summit and his visit to Vietnam News conference by Dmitry Medvedev on the outcome of the APEC summit and his visit to Vietnam // The Russian Government. November 19, 2018. URL: http:/government.ru/en/ news/34763/ (accessed: 21.11.2018); Statistical Review of World Energy 2017 // BP. URL: https:/www.bp.com/content/dam/bp-country/de_ch/PDF/bp-statistical-review-of-world-energy-2017full-report.pdf (accessed: 04.06.2018). 


\section{REFERENCES}

Baev, P.K. \& Tonnesson, S. (2015). Can Russia Keep its Special Ties with Vietnam while Moving Closer and Closer to China? International Area Studies Review, 18(3), 312-325. DOI: $0.1177 / 2233865915596709$.

Cherry, H. (2018). Vietnam. Nothing Ever Dies: Vietnam and the Memory of War By Viet Thanh Nguyen. Cambridge, MA: Harvard University Press, 2016. P. 374. Plates, Notes, Bibliography, Index. Journal of Southeast Asian Studies, 49(1), 177-179. DOI: 10.1017/S002246341700087X.

Filimonova, N. (2015). Russia - Vietnam: Cooperation in the Arctic? The Diplomat. December 11. URL: https://thediplomat.com/2015/12/russia-vietnam-cooperation-in-the-arctic/ (accessed: 15.09.2018).

Istomin, I.A. (2018). Comparative Analysis of the Russian Foreign Policy Priorities and Research Interests of the National Academic Community. Vestnik RUDN. International Relations, 18(1), 66-84. DOI: 10.22363/2313-0660-2018-18-1-162-185. (in Russian).

Kobelev, E.V. (2015). Russian-Vietnamese Relations: Reality and Prospects. In: Vietnamese Studies. Vol. 5: National Interests and Traditions of Vietnam. Moscow: Institute of the Far East of the Russian Academy of Sciences, p. 21-43. (in Russian).

Kostunina, G.M. (2018). Free Economic Zones in the Practice of Vietnam. In: South-East Asia: Relevant Problems of Development. Moscow, p. 121-135. (in Russian).

Kozyrev, V. (2014). Russia-Vietnam Strategic Partnership: The Return of the Brotherhood in Arms? Russian Analytical Digest, 145, 8-11. URL: http://www.css.ethz.ch/content/dam/ethz/specialinterest/gess/cis/center-for-securities-studies/pdfs/RAD-145-8-11.pdf (accessed: 26.08.2018).

Le Viet Trung et al. (2016). An Overview of Vietnam's Oil and Gas Industry. Journal on Petroleum Economics \& Management, 10, 64-71.

Mazyrin, V.M. (2012). Russia and Vietnam: Building a Strategic Partnership. Russia and ASEAN-4: Potential and Realms of Cooperation. In: Russia - ASEAN: Foundations and Prospects of a 15-year Old Partnership. Singapore: ISEAS, p. 173-183.

Mazyrin, V.M. (Eds.). (2016). New Calls and the Mechanisms of Security in East Asia. Moscow: Forum.

Mikhoko, K. (2015). Special Features and Tasks of Development of the Russian-Vietnamese Strategic Partnership (2000-2014). In: Vietnamese studies. Vol. 5: National Interests and Traditions of Vietnam. Moscow: Institute of the Far East of the Russian academy of sciences, p. 55-72. (in Russian).

Narkhova, E.I. (2017). The Analytic Review of Vietnamese Literature on the Problems of South China Sea. In: South-East Asia: Actual Problems of Development, 37. Moscow: The Institute of the Oriental Study, p. 121-131.

Nguen Minh Ngoc. (2013a). South China Sea: Geopolitics, Interests, Course and the Activity of the Interested Countries. Hanoi: World Publishing House. (in Vietnamese).

Nguen Minh Ngoc. (2013b). South China Sea: Control over the Situation and Methods of the Solution. Hanoi: World Publishing House. (in Vietnamese).

Nguen Minh Ngoc. (2015). Interests and policy of Japan, Russia, India and Australia in the South China sea. In: Search for the Solution into the Name of Peace and Justice in the South China Sea. Hanoi, p. $34-61$.

Skopin, A.Y. (2018). Strategy of Russia in the World, Eurasia and South-Eastern Asia. In: SouthEast Asia: Relevant Problems of Development. Moscow, p. 28-34. (in Russian).

Tsvetkova, N.N. (2015). Anti-Russian Sanctions and the Problem of Diversification of Commercial and Economic Connections of the Russian Federation. East between West and Russia. Ed. by A.M. Khazanov. Moscow: Institute of Oriental Study, p. 74-94. (in Russian).

Zelenkova, M.S. (2018). Perspectives of Vietnam Return to the Construction of NPP. South-East Asia: Relevant Problems of Development. Moscow, 1(1 (38)), p. 177-188. (in Russian).

Received: 21.11 .2018 
For citations: Nguyen Thi Ngoc Lan \& Chernenko, E.F. (2018). Russian-Vietnamese Cooperation in Energy Sector. Vestnik RUDN. International Relations, 18 (4), 906-924. DOI: 10.22363/23130660-2018-18-4-906-924.

\begin{abstract}
About the authors: Nguyen Thi Ngoc Lan - Master Student, Theory and History of International Relations, People's Friendship Univeristy of Russia (RUDN University) (e-mail: 1032165943@rudn.ru).

Chernenko Elena Fedorovna - PhD in Economics, Associate Professor, Peoples' Friendship University of Russia (RUDN University) (e-mail: chernenko-ef@rudn.ru).
\end{abstract}

\title{
DOI: 10.22363/2313-0660-2018-18-4-906-924 \\ Российско-вьетнамское сотрудничество в энергетике
}

\author{
Нгуен Тхи Нгок Лан, Е.Ф. Черненко \\ Российский университет дружбы народов, \\ Москва, Российская Федерация
}

\begin{abstract}
Обилие энергетических ресурсов, в том числе возобновляемых и невозобновляемых, является центральным элементом развития энергетического сектора. Тем не менее, другие решающие факторы, такие как технологии и человеческие ресурсы, превращают ресурсы, дарованные природой, в экономическую выгоду для обеспечения качества. В 1950-х гг. молодая Демократическая Республика Вьетнам сделала приоритетной задачу формирования энергетического сектора в плане экономического развития, чтобы быть более самостоятельной в сфере энергетической безопасности. Единственным международным источником поддержки для страны в то время были союзникикоммунисты. Советский Союз взял на себя основную ответственность как крупнейший благотворитель для Демократической Республики Вьетнам в военное время. В дополнение к военным и материально-техническим средствам для борьбы Демократической Республики Вьетнам в Северном Вьетнаме с поддерживаемым США правительством Республики Вьетнам в Южном Вьетнаме за объединение Советский Союз также активно поддерживал своего партнера в реализации пятилетних экономических планов для развития социализма, включая формирование и развитие энергетического сектора. В послевоенное время СССР продолжал поддерживать недавно объединенную страну, Социалистическую Республику Вьетнам, для развития энергетического сектора как своего передового экономического сектора.

Российская Федерация и Вьетнам продолжают углублять двустороннее сотрудничество в области энергетики с успешным управлением многомиллиардными совместными предприятиями в нефтегазовой отрасли и реализуют многие проекты в энергетическом секторе. Партнерство в энергетической сфере становится наиболее заметной областью сотрудничества за 68 -летнюю историю двусторонних отношений.

Статья посвящена вопросам сотрудничества России и Вьетнама в энергетике. Авторы акцентируют внимание на ведущей роли СССР, а после его распада России в формировании и развитии энергетики Вьетнама. Рассмотрены конкретные проекты совместной деятельности. В статье анализируется эволюция отношений двух стран в разные исторические периоды. Подчеркивается, что развитие национальной энергетики для Вьетнама является важнейшей сферой российско-вьетнамских двусторонних отношений на протяжении всей их истории и, безусловно, одним из приоритетов для Вьетнама в настоящее время. В свою очередь, Россия с учетом своих внешнеполитических ориентиров нацелена на активизацию сотрудничества с Вьетнамом с перспективой расширения границ взаимодействия с этой страной не только в энергетической сфере.
\end{abstract}

Ключевые слова: энергетический сектор, нефтяная и газовая промышленность, двустороннее сотрудничество, Северный Вьетнам, Южный Вьетнам, Советский Союз, Россия

Благодарности: Работа выполнена в рамках гранта РФФИ № 18-514-92003/18. 


\section{БИБЛИОГРАФИЧЕСКИЙ СПИСОК}

Зеленкова М.С. Перспективы возврата Вьетнама к вопросу строительства АЭС // Юго-Восточная Азия: актуальные проблемы развития. 2018. Т. 1. № 1 (38). С. 177-188.

Истомин И.А. Сравнительный анализ приоритетов российской внешней политики и научнообразовательного сообщества специалистов по международным отношениям // Вестник Российского университета дружбы народов. Серия: Международные отношения. 2018. T. 18. № 1. C. 66-84. DOI: 10.22363/2313-0660-2018-18-1-162-185.

Кобелев Е.В. Российско-вьетнамские отношения: реальность и перспективы // Вьетнамские исследования. Вып. 5. М.: Институт востоковедения РАН, 2015. С. $21-43$.

Костюнина Г.М. Свободные экономические зоны в практике Вьетнама // Юго-Восточная Азия: актуальные проблемы развития. 2018. № 2 (39). С. 121-135.

Михоко K. Особенности и задачи развития российско-вьетнамского стратегического партнерства (2001-2014 гг.) // Вьетнамские исследования. Вып. 5. М.: Институт востоковедения PAH, 2015. С. 55-72.

Нархова Е.И. Аналитический обзор вьетнамской литературы по проблематике ЮжноКитайского моря // Юго-Восточная Азия: актуальные проблемы развития. 2017. № 37. C. $121-131$.

Нгуен Минь Нгок. Южно-Китайское море: геополитика, интересы, курс и деятельность заинтересованных стран. Ханой: World Publishing House, 2013а. (на вьет. яз.).

Нгуен Минь Нгок. Южно-Китайское море: контроль над ситуацией и методы решения. Ханой: World Publishing House, 2013б. (на вьет. яз.).

Новые вызовы и механизмы безопасности в Восточной Азии / под ред. В.М. Мазырина. М.: ФОРУМ, 2016.

Скопин А.Ю. Стратегия России в мире, Евразии и Юго-Восточной Азии // Юго-Восточная Азия: актуальные проблемы развития. 2018. № 2 (39). С. 28 - 34.

Цветкова Н.Н. Антироссийские санкции и проблема диверсификации торгово-экономических связей РФ // Восток между Западом и Россией / под ред. А.М. Хазанова. М.: Институт востоковедения РАН, 2015. С. 74-94.

Baev P.K., Tonnesson S. Can Russia Keep its Special Ties with Vietnam while Moving Closer and Closer to China? // International Area Studies Review. 2015. Vol. 18. N 3. P. 312-325. DOI: $0.1177 / 2233865915596709$.

Cherry H. Vietnam. Nothing Ever Dies: Vietnam and the Memory of War By Viet Thanh Nguyen. Cambridge, MA: Harvard University Press, 2016. P. 374. Plates, Notes, Bibliography, Index // Journal of Southeast Asian Studies. 2018. Vol. 49. N 1. P. 177-179. DOI: 10.1017/S002246341700087X.

Filimonova N. Russia - Vietnam: Cooperation in the Arctic? // The Diplomat. December 11, 2015. URL: https://thediplomat.com/2015/12/russia-vietnam-cooperation-in-the-arctic/ (accessed: 15.09.2018).

Kozyrev V. Russia-Vietnam Strategic Partnership: The Return of the Brotherhood in Arms? // Russian Analytical Digest. 2014. N 145. P. 8-11. URL: http://www.css.ethz.ch/content/ dam/ethz/special-interest/gess/cis/center-for-securities-studies/pdfs/RAD-145-8-11.pdf (accessed: 26.08.2018).

Le Viet Trung, Tran Quoc Viet, Pham Van Chat. An Overview of Vietnam's Oil and Gas Industry // Journal on Petroleum Economics \& Management. 2016. Vol. 10. P. 64-71.

Mazyrin V.M. Russia and Vietnam: Building a Strategic Partnership. Russia and ASEAN-4: Potential and Realms of Cooperation // Russia - ASEAN: Foundations and Prospects of a 15-year Old Partnership. Singapore: ISEAS, 2012. P. 173-183.

Nguen Minh Ngoc. Interests and policy of Japan, Russia, India and Australia in the South China Sea // Search for the Solution into the Name of Peace and Justice in the South China Sea. Hanoi. P. $34-61$. 
Для цитирования: Nguyen Thi Ngoc Lan, Chernenko E.F. Russian-Vietnamese Cooperation in Energy Sector // Вестник Российского университета дружбы народов. Серия: Международные отношения. 2018. Т. 18. № 4. С. 906-924. DOI: 10.22363/2313-0660-2018-18-4-906924.

Сведения об авторах: Нгуен Тхи Нгок Лан - магистрант кафедры теории и истории международных отношений, Российский университет дружбы народов (e-mail: 1032165943@rudn.ru).

Черненко Елена Федоровна - кандидат экономических наук, доцент кафедры теории и истории международных отношений Российского университета дружбы народов (e-mail: chernenko-ef@rudn.ru).

(C) Nguyen Thi Ngoc Lan, Chernenko E.F., 2018 